\title{
Geodynamic Evolution of the Western Part of the Russian Arctic and Its Diamond Potential
}

\author{
N. O. Sorokhtin ${ }^{a, *}$ and N. E. Kozlov ${ }^{b, * *}$ \\ a Shirshov Institute of Oceanology, Russian Academy of Sciences, Moscow, 117218 Russia \\ ${ }^{b}$ Geological Institute, Kola Science Center, Russian Academy of Sciences, Apatity, 184209 Russia \\ *e-mail:nsorokhtin@ocean.ru \\ **e-mail:kozlov.ne@yandex.ru
}

Received November 9, 2020; revised February 3, 2021; accepted April 19, 2021

\begin{abstract}
The study of the geodynamic evolution of the Baltic Shield showed that the melts of diamondiferous kimberlites and related rocks were formed due to the pulling of "heavy" ferruginous sediments of the Early Proterozoic into subduction zones beneath the Archean cratons. Later, during the Neoproterozoic and Paleozoic stages of rifting, melts conserved in the lower crust and subcrustal lithosphere were able to penetrate into the near-surface zones of the crust and form magmatic complexes of alkaline-ultramafic and kimberlite magmatism. The authors showed that diamondiferous kimberlite and lamproite explosion pipes, as well as related carbonatite and alkaline-ultramafic intrusions, are mainly located above the subduction zones of the Svecofennian (Karelian) plates, which functioned about 2.0-1.8 Ga ago. At the same time, alkaline ultramafic intrusions and (sodium) carbonatites are located closest to the front of the subduction zone of Proterozoic plates (from 100 to $200-300 \mathrm{~km}$ ). Then (at a distance of 200 to $400 \mathrm{~km}$ ), there is a zone of location of calcite carbonatites and melilitites, and sometimes nondiamondiferous kimberlites. Diamondiferous kimberlite and lamproite diatremes are located farther than other similar formations approximately 300 to 600$650 \mathrm{~km}$ from its front. Such a regular spatial arrangement of magmatic complexes of a single series unambiguously indicates a change in depth of their origin. The farther from the surface boundary of the paleosubduction zone the magmatic bodies are located, the deeper the facies representing them.
\end{abstract}

Keywords: diamonds, kimberlites, lamproites, explosion pipes, diatremes, Arctic, diamondiferous, Svecofennian, Baltic Shield

DOI: $10.1134 / \mathrm{S} 0001437021060138$

\section{INTRODUCTION}

Earlier, in a number of studies, we showed that all the material of kimberlite, carbonatite, and alkalineultramafic magmas occurred due to remelting of pelagic sediments pulled along subduction zones to great depths beneath continents [22, 23, 31]. Indeed, the isotopic compositions of carbon in diamonds cannot be explained without the involvement of crustal material [5]. A similar situation is observed in hightemperature deep-seated rocks of the carbonatite and kimberlite association. Their carbon and oxygen isotopic compositions show that crustal carbon dioxide of primary sedimentary origin takes part in the formation of the carbonate material of these rocks [13]. Analyzing sulfur isotope shifts and lead isotope ratios from sulfide inclusions in diamonds, Eldridge et al. [27] reached similar conclusions, while confirming the ancient age of diamond formation (about $2 \mathrm{Ga}$ ).

However, ordinary modern-type sediments, due to their low density, cannot be pulled to great depths in large volumes. For this, the density of sediments entering into subduction zones had to exceed the average density of continental plates [31]. However, such iron-rich and therefore dense (heavy) pelagic sediments were formed only in the Early Precambrian; they could have only been pulled ("fallen") along paleosubduction zones to great depths under Archean continental shields.

\section{GEODYNAMIC EVOLUTION OF THE EASTERN BALTIC SHIELD}

The internal structure of the Baltic Shield was mainly formed as a result of the Sveco-Karelian tectogenesis about 1.9-1.8 Ga ago, which fused together individual Archean blocks and shields. At present, the Baltic Shield includes two regions of crust that differ in age and structure: the Archean Karelia-Kola (in the east of the Baltic Shield) and the Early Proterozoic or Svecofennian in the west. Close to the modern one, the boundary of the shield was formed in the Caledonian, when in its northwestern part, the thick fold belt of the Caledonides was formed, which overprinted the 
Archean and Proterozoic formations as a result of closing of the Proto-Atlantic Iapetus Ocean. The southeastern part of the shield has gently subsided under Riphean-Paleozoic volcano-sedimentary deposits of the northern part of the Russian Plate. The northern and northeastern boundary runs along the Murmansk coast and is limited by the Karpinsky fault system, where a sharp stepwise subsidence of the crystalline basement under the Timanides and Barents Sea Platform is observed.

The continental blocks of the Kola Peninsula and Karelia, adjoined by the territory of Arkhangelsk oblast from the east, were formed in the Late Archean 3.5-2.7 Ga ago [10]. At the end of the Archean, about 2.7-2.6 Ga ago, they combined along the Belomorides fold belt as a result of the global Kenoran diastrophism, which combined all previously scattered Archean shields into the single Monogea supercontinent. For the first $100 \mathrm{Ma}$ of its existence, the eastern part of the Baltic Shield developed in a platform regime. However, the emplacement of layered mafic-hyperbasic intrusions into Archean crust 2.49-2.39 Ga ago [1] marked the first pulses of extension of Archean crust and initiation of paleorifts, which later formed the Early Proterozoic greenstone belts.

2.0-1.8 Ga ago, the geodynamic setting on the Baltic Shield was replaced by a ubiquitous compression regime, which led to consolidation of the continental crust and the formation of its main tectonic plan. The closing of Early Proterozoic oceanic basins was accompanied by large-scale absorption of oceanic crust in plate subduction zones southwest of the Archean Kola Plate (Fig. 1). As a result of the collision that occurred after this, the Karelia-Kola continent and Svecofennian region formed a single continent.

The Svecofennian folded region occupies the central part of the Baltic Shield and borders the Karelian granite-greenstone region from the northeast. It was formed in the Early Proterozoic due to development of a system of island arcs in the vast paleocean that existed then between the Karelia-Kola and Canadian Archean cratons. At the end of the Early Proterozoic, about $2 \mathrm{Ga}$ ago, the Svecofennian Ocean began to close, which led to the formation of a multitiered suture system. This system in the modern literature has been called the Svecofennian folded region. This area is a complex system of volcano-sedimentary complexes, broken by synorogenic gabbro-tonalite and gabbro-granodiorite magmatic bodies. The geochemistry of these rocks indicates that this structural-material complex belongs to island arc formations [28]. All these data allow us to consider the described volcanoplutonic associations of Svecofennides as magmatic complexes of ancient island arcs, the collisions of which led to the formation of the region's continental crust. Among the island arc series are fragments of oceanic crust, which have the characteristic features of ophiolite complexes. The intrusive and volcanic part of the ophiolite sections consists of ultramafic and mafic tholeiitic rocks, which occupy the bulk of such belts. The sedimentary part is represented by albitized clayey sediments, pelites, carbonates, conglomerates, siliceous assemblages, and graphite-sulfide crystalline schists. There are also numerous interlayers of ferruginous quartzites [26]. Among the volcanic section of greenstone belts, basalts frequently have pillow lava structures. The geochemical characteristics of the ophiolite complexes of the Svecofennides revealed some of their differences in a number of elements. Thus, the older ones (2.4-2.2 Ga) are noticeably enriched in $\mathrm{Fe}$ and $\mathrm{Mg}$.

The features of the spatial location, internal structure, and formation age of volcano-sedimentary complexes suggest the presence in the Karelia-Kola megablock and in the Svecofennian region of at least four to five paleosubduction zones dipping to the northeast (Fig. 1). The first of them crosscuts the Archean continental Karelia-Kola Plate in the southeast direction south of the Belomorian fold belt. The Belomorides were formed in the late Archean (2.9-2.8 Ga ago). However, at the end of the Early Proterozoic, the belt underwent intense tectonic reworking due to the collision of the Kola and Karelian continental blocks. The Belomorian belt is a typical granulite-gneiss collisional belt of the cover structure [20]. Further northeast, it most likely plunges under the Kola granulitegneiss craton. The second subduction zone has been distinguished by us indirectly, but it also intersects the Karelia-Kola megablock south of the first zone and plunges to the northeast. Finally, the third, best expressed plate subduction zone frames the KareliaKola Archean megablock from the southwest and is marked by a change in the age characteristics of rocks from Archean in the northeast to Early Proterozoic in the southwest. In addition, to the northeast of this zone, the formation age of the continental margins varies within 2.4-2.2 Ga, while to the southwest, the island arc complex is rejuvenated up to $2.1-1.9 \mathrm{Ga}$ [26]. The fourth zone of the inferred paleosubduction zone is not as unambiguously distinguished, but it can be traced along the boundary of changes in the material content of protoceanic and island arc associations [26]. Conversely, the fourth and fifth zones are quite clearly recorded based on geophysical data obtained as a result of the Babel seismic project in the Gulf of Bothnia [26]. At the same time, geophysical data also indicate subsidence of paleooceanic plates under the Karelia-Kola Archean megablock.

It should be noted that the thickness of the Archean continental plates by the end of the Early Proterozoic already reached values of $\sim 200-250 \mathrm{~km}$ [11]. Consequently, at characteristic angles of inclination $\left(20^{\circ}-\right.$ $25^{\circ}$ ) of the subducted oceanic lithosphere, the horizontal distance between the subduction front of this plate and the kimberlite melt generation zone at a depth of about $250 \mathrm{~km}$ under the Archean craton could be from 300 to $600-650 \mathrm{~km}$. 

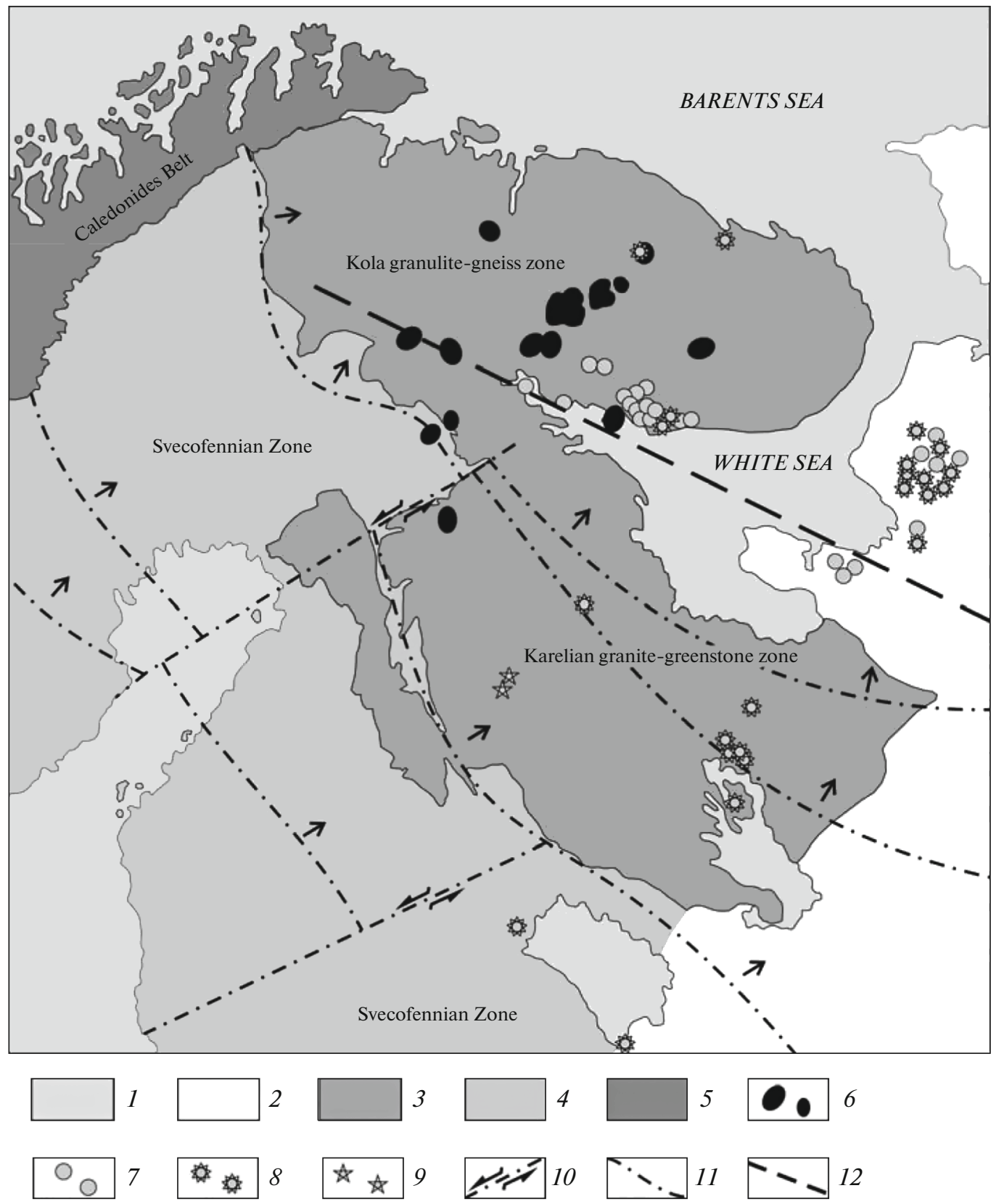

Fig. 1. Geological sketch map of eastern part of Baltic Shield: (1) hydrosphere; (2) sedimentary cover of Russian Platform; (3) continental crustal associations of Archean; (4) Early Proterozoic (Svecofennian) volcano-sedimentary and intrusive complexes; (5) Caledonian allochthonous covers; (6) alkaline-ultramafic intrusion; (7) explosion pipes of picrite and melilitite composition; (8) kimberlites; (9) lamproites; (10) transform faults; (11) subduction zones and directions of subducting oceanic plates (shown by arrows) of Early Proterozoic age (1.9-1.8 Ga ago); (12) axis of Paleozoic Kandalaksha-Dvina rift system.

An interesting feature of most active margins of the Archean continents in the Early Proterozoic is their almost complete amagmatic nature [22, 23]. This remarkable feature makes it difficult to use an actualistic approach to identifying plate subduction zones, because the time period of 2.0-1.8 Ga ago was characterized by the most intense accumulation of jaspilitetype iron ore sediments on the ocean floor in Earth's history. Upon entering plate subduction zones, they acted as a "lubricant," sharply reducing the friction temperature of the plates below the andesitic magma generation temperature. At the same time, they made the oceanic plate significantly heavier, allowing it to move under the Archean continent at a higher rate.

The final closing of the Svecofennian Ocean took place about 1.9-1.8 Ga ago. From then to the present 
day, the Karelia-Kola megablock of Archean crust and adjacent Early Proterozoic structures of the Svecofennides are characterized only by platform regimes of continental crust development.

\section{GEODYNAMIC EVOLUTION OF THE WESTERN PART OF THE RUSSIAN ARCTIC}

During the evolution of the East European Platform (EEP), its northern and northwestern (in modern points) termini, starting from the Paleoproterozoic, periodically underwent breakup and collisions with the North American lithospheric plate [25]. This, in particular, is indicated by the comparability of the structural-material complexes of the Baltic Shield Svecofennides and Ketilides of southern Greenland and Canada, which formed about 1.9-1.8 Ga ago during closing of the Svecofennian Paleoocean during the formation of Megagea. Later, in the Peritman region and in the Kandalaksha-Dvina basin about 1350-1050 Ma ago, the basement subsided and continental terrigenous sediments accumulated with an admixture of volcanic rocks [25]. At the same time, in the northeast of the Russian Plate, shelf and slope sedimentary complexes of the continental passive margin formed, known today as the Timan-Varanger belt of the Baikalides. The data on these processes agree with the factual material on the breakup of Megagea ( $1.7 \mathrm{Ga}$ ago), which continued until the Late Riphean ( 1000 Ma ago), when the next supercontinent in Earth's history, Mesogea (Rodinia), formed [22, 31]. At this time, in the northwestern peripheral zone of the EEP, the Dalsland folded region was formed, which is a continuation of the Grenville Belt in Canada and Greenland and marks the closing zone of the Paleoiapetus Ocean (not to be confused with the Iapetus Ocean, which formed later).

From 1350 to $535 \mathrm{Ma}$ ago, the northeastern part of the EEP developed in a peneplanation regime, which inevitably should have led to accumulation of huge sediment masses on the shelf, slope, and its foot. During this epoch, the continent successively migrated from the near-equatorial zone of the Earth (about 1.0 Ga ago), where it was at the time Mesogea was forming, to the circumpolar regions $(800-650 \mathrm{Ma}$ ago), then back again (about $550 \mathrm{Ma}$ ago) [31, 33, 34]. In the Vendian (600-535 Ma ago), its peneplanation processes led to the formation of a continental terrigenous sediment complex with traces of tillites in the northwest and coastal marine formations in the north near the Varanger Peninsula [29] (Fig. 2). The northern and northeastern margins of the Russian plate also represented the passive continental margin, at the boundary of which the accumulation of shelf and continental slope formations continued. The events of the Dalslandic orogeny in the west of the Baltic Shield led to the formation of a number of grabenlike systems regularly spatially located in its northeastern regions (the Kandalaksha-Dvina graben in the White Sea). At the same time, their tectonic formation conditions were distinctly reflected, as evidenced by their almost complete amagmatic nature in the Riphean. Only at the northern end of the Kola Peninsula and on the Sredny and Rybachy peninsulas have researchers noted rare magmatic bodies and dolerite dikes attributed to this period.

At present, Riphean formations of the passive margin of the north and northeast (in modern points) Russian Plate outcrop on the Varanger Peninsula in northern Norway; the Sredny and Rybachy peninsulas and Kildin Islands at the northern tip of the Kola Peninsula; and on the Kanin Nos Peninsula and Timan Inlier in Arkhangelsk oblast. In the geological literature, these formations are distinguished as the Timan-Varanger system of the Baikalides $[14,19]$ and represent monoclinal bedding of the Middle, Upper Riphean, and Vendian weakly metamorphosed sedimentary complexes, tectonically upthrown, and locally thrust over Archean and Lower Proterozoic formations of the Baltic Shield and Russian Plate [18]. According to seismic data, the surface of the monocline plunges gently towards the South Barents Sea basin at angles of $2^{\circ}-5^{\circ}$, then $5^{\circ}-10^{\circ}[9,19]$.

In the Late Vendian-Early Cambrian, about 570$510 \mathrm{Ma}$ ago, the northern and northeastern termini of the Paleo-Russian Plate joined the Grenvillean North Kara-Barents-Pechora Plate, which subsequently separated into the Barents, North Kara, and Pechora plates $[25,30,31]$. At the same time, to the northwest, the Iapetus Ocean still existed, which formed after the breakup of Mesogea (Rodinia). The EEP increment in this part of it proceeded without folding or magmatism, and the junction of the two continents occurred along a shear zone, similar to the blocks of lithosphere displaced along a transform fault (Fig. 2).

The collision of two plates resulted in uplift and local thrusting of shelf and continental-slope sedimentary complexes of the Middle and Upper Riphean and Vendian to the margin of the EEP and the formation of large right-lateral strike-slip and thrust structures in the region of the Sredny and Rybachy peninsulas. The data of [19] reveal that the formation processes of the Timan-Varanger suture zone are associated with a sharp decrease in the thickness of the section in the northwestern (Kola-Kanin) segment and its manifold increase in the southeastern (Timan) direction. It should be added that the section does not contain Lower Riphean formations, and only in the southeastern part of the Timan-Varanger suture zone are coeval sediments found [25].

The basement of the North Kara-BarentsPechora Plate outcrops within the Nordaustlandet of Svalbard, the northern part of Novaya Zemlya, and on the Taimyr Peninsula. It was exposed by drilling on the islands of Franz Josef Land and within the Pechora Plate. The section is represented by semifolded and 


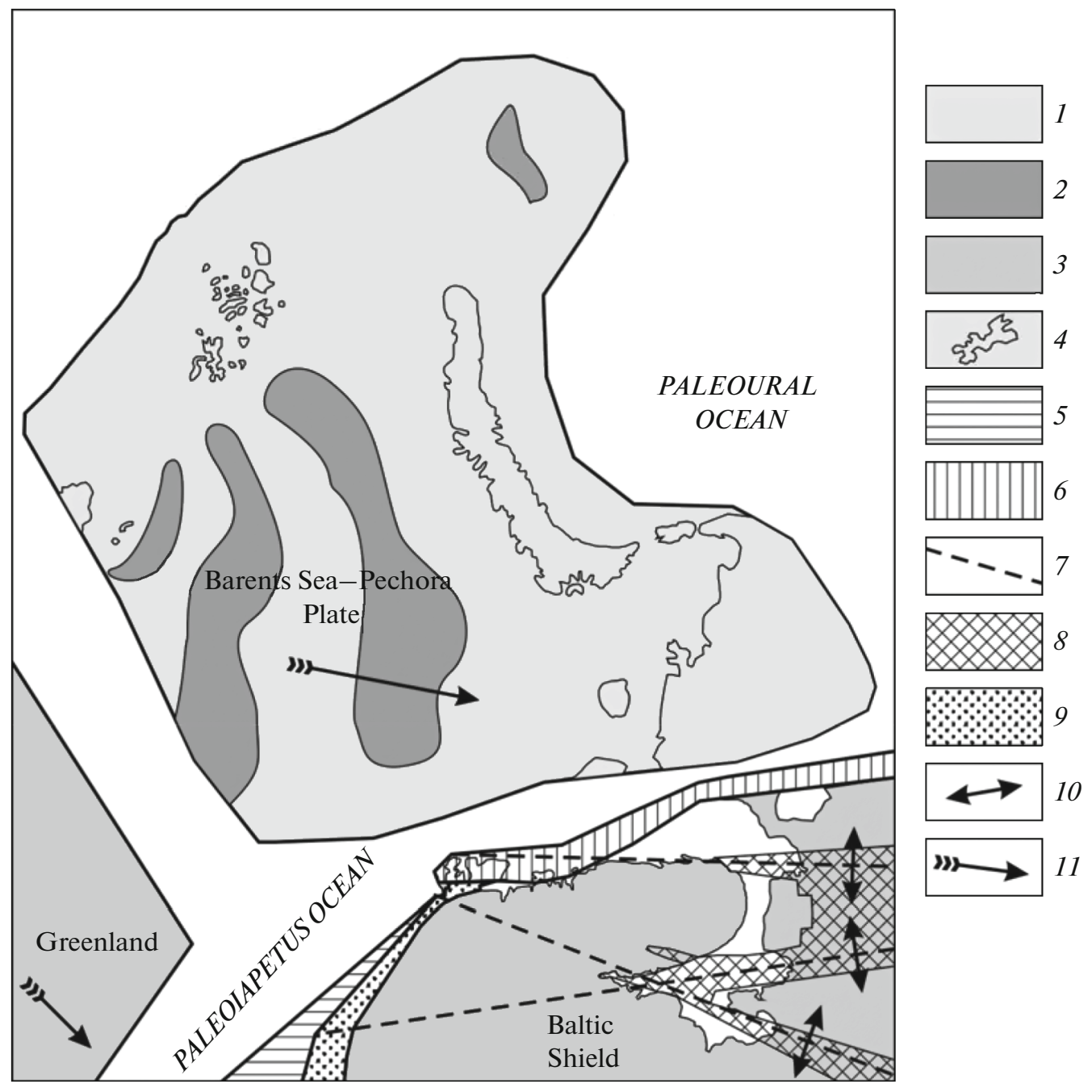

Fig. 2. Paleogeodynamic reconstruction of northern part of EEP and adjacent Arctic Basin in Middle Riphean-Vendian (1350$540 \mathrm{Ma}$ ago): (1) inferred contours of Barents Sea-Pechora Plate; (2) inferred areas of oceanic crust; (3) contours of ancient (Archean) lithosphere of Baltic Shield and Greenland; (4) contours of modern coastline; (5) folded formations of Middle-Upper Riphean of Dalsland region (1200-900 Ma ago); (6) Middle-Upper Riphean and Vendian sedimentary complexes of shelf and continental slope of passive margin of northeastern part of Baltic Shield and Russian Plate (1350-620 Ma ago); (7) main lineaments on Baltic Shield, (8) Upper Riphean rift formations; (9) Vendian continental terrigenous sediments (650-570 Ma ago); (10) stress field vectors in continental lithosphere; (11) generalized direction of lithospheric plate movement.

metamorphosed, under epidote-amphibolite facies conditions, gneiss and crystalline schist; biotite and two-mica, carbonaceous, and graphite-bearing, chlorite-sericite schists; and quartzite, marble, dolomite, calciphyre, and conglomerate. These complexes are crosscut by Riphean and Vendian granites. The age of the basement is $1.55-1.3 \mathrm{Ga}[2,15,25]$. This lithospheric plate has an inhomogeneous basement structure, expressed in adjacent continental (granite) and suboceanic sectors. However, it should not be forgotten that its western part was formed and augmented during the Caledonian folding phase and reflects the conditions of closing of the Iapetus Ocean.

Somewhat later, the Paleoural Ocean closed in the east. Just as with closing of the Iapetus Ocean, the for- mation of the Ural fold system was accompanied by multistage and uneven convergence and subduction of the Paleo-EEP under the active margin of the West Siberian Plate. This led to the formation of a collisional structure with complex configuration from the Late Devonian-Early Carboniferous ( $\sim 350 \mathrm{Ma}$ ago) in the south to the Early Triassic ( $\sim 265 \mathrm{Ma}$ ago) in the north [14]. At the northern end of the forming folded system, the passive margin of the North Kara Plate was thrust over the Siberian Craton, forming the Taimyr fold system and Yenisei-Khatanga foredeep. The complete closing of the Paleoural Ocean is marked by the development of postcollisional granites with an age of $264 \mathrm{Ma}$ [15]. As a result, an orogenic structure formed between the EEP and the West Sibe- 


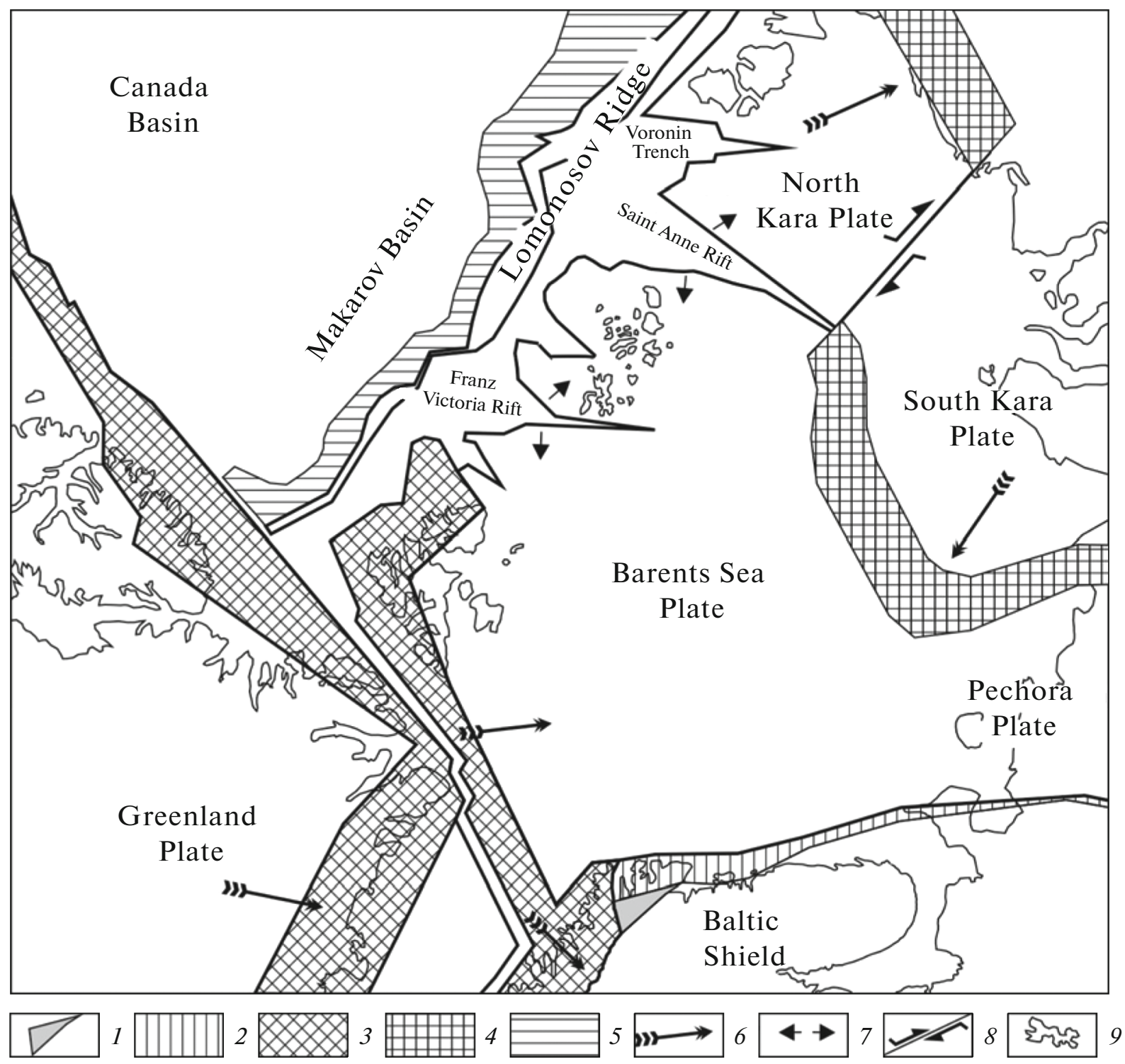

Fig. 3. Paleogeodynamic reconstruction of northern part of EEP, West Siberian Plate, and adjacent Arctic Basin in Paleozoic and Early Mesozoic (650-241 Ma ago): (1) Vendian continental terrigenous sediments (650-570 Ma ago); (2) Middle-Upper Riphean and Vendian sedimentary complexes of shelf and continental slope of passive margin of northeastern part of Baltic Shield and Russian Plate; (3) folded formations of North Atlantic Caledonian in Early Ordovician, Late Devonian (505-362 Ma); (4) folded formations of Polar Urals, Novaya Zemlya, and Taimyr Peninsula i Early Permian, Early Triassic (290-241 Ma ago); (5) passive margin of continent; $(6)$ generalized direction of lithospheric plate movement; (7) stress field vectors in continental lithosphere; (8) transform fault; (9) contour of modern coastline.

rian Plate, which has multidirectional, sometimes arcuate, up to acutely oriented fold zones, locally complicated by transform faults. Such an example is the the Polar Urals, Pai-Khoi, Novaya Zemlya, and Taimyr Peninsula fold systems (Fig. 3).

The closing of the northern part of the Paleoural Ocean led to an almost simultaneous collision of three continental plates with a basement of different ages. Here it should be borne in mind that, according to the laws of plate tectonics, an older plate always subducts (pushes) beneath a younger of the same type. That is, when two oceanic or two continental plates collide, the ancient one always subducts beneath the young one. Consequently, with a basement age of 1.55-1.3 Ga, the Barents Sea-Pechora Plate subducted in its southern part beneath the younger West Siberian Plate and was obducted in the north onto the ancient Siberian Platform.

As a result of completion of the Caledonian and Hercynian stages of tectogenesis, the Pangea supercontinent was formed, in the northern part of which the lithospheric plates of the ancient North American, 

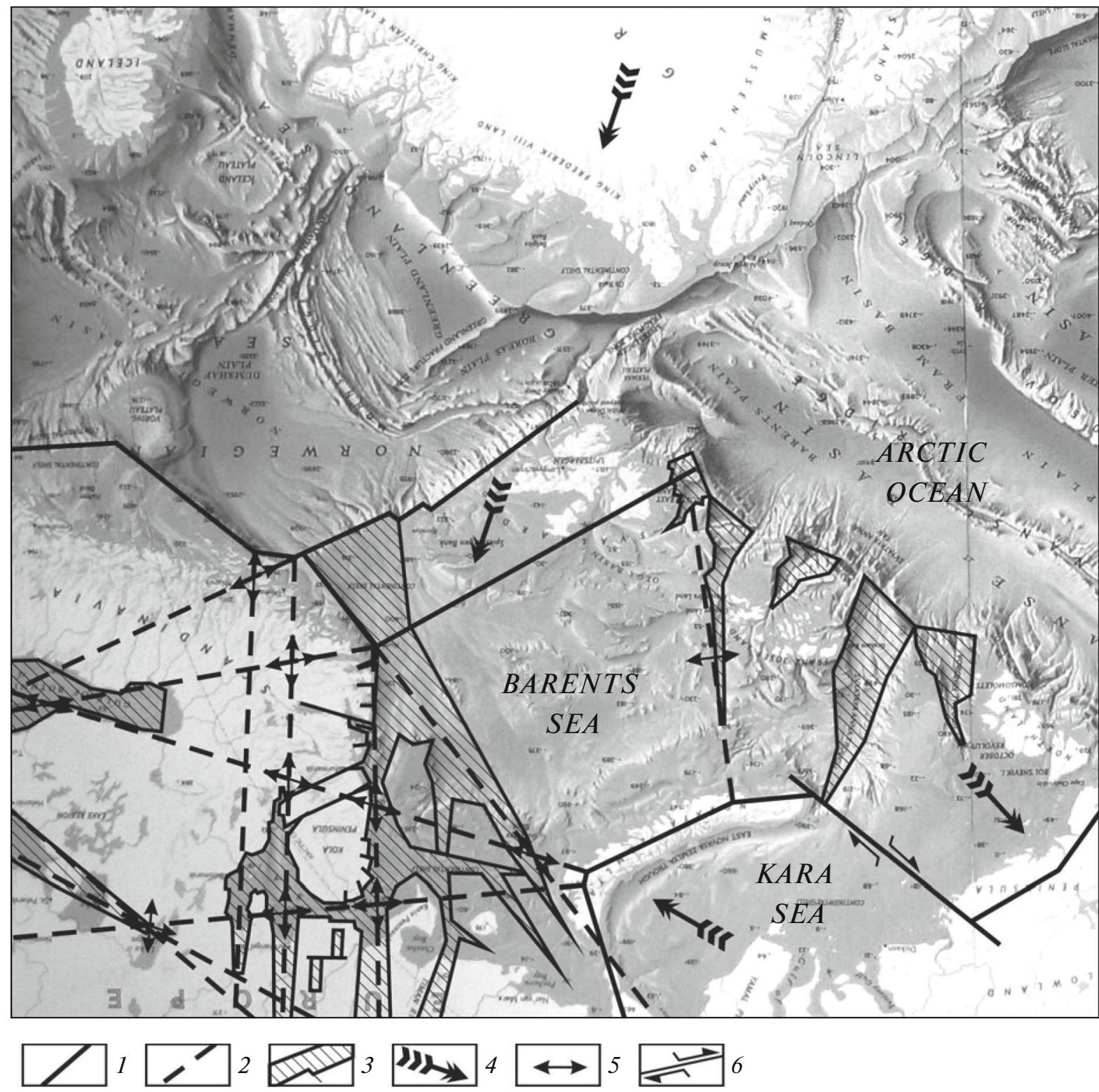

Fig. 4. Reconstruction of faults in ancient East European, young West Siberian, and ancient Siberian platforms in Paleozoic, Early Mesozoic (650-241 Ma ago). (1) Lithospheric plate boundary along which closing of paleoceans and collision took place; (2) main lineaments formed in continental lithospheric plate; (3) rifts; (4) generalized direction of lithospheric plate movement, (5) stress fields vectors in continental lithosphere; (6) transform fault.

East European, and Siberian cratons were collisionally aligned. Young lithospheric plates with a Grenvillean basement were sandwiched between, including the young West Siberian and North Kara-Barents Sea-Pechora platforms. Apparently, at the same time, the large oceanic Amerasian Basin was also formed, the main part of which is occupied by the Canada Basin.

The closing the Iapetus Paleoocean can be reconstructed from the modern configuration of the continental plates of North Atlantic and from stripes of magnetic anomalies, as well as from the structure of the allochthonous Caledonian Plate in the northern part of the Baltic Shield, marking an ancient junction zone. In this case, the wedge shape of the eastern part of the Greenland Plate upon collision with the East European Plate, should have led to a series of tensile stresses in the northern part of the Baltic Shield along the Northern Norway-Kola Peninsula- Arkhangelsk oblast line, i.e. from northwest to southeast [21] (Figs. 3, 4).

Similarly, during closing of the CarboniferousTriassic Paleoural Ocean and during the collision of the West Siberian Epipaleozoic Platform with the East European Platform, a zone of tensile stresses apparently formed along the Novaya Zemlya-Novy Nokuev 
Island-Kandalaksha-Gulf of Bothnia and NovayaZemlya-White Sea Strait-lakes Onega and Ladoga lines (Fig. 4). The protrusion of the Kara Plate, marked by the kneelike bend of Novaya Zemlya folded structures, penetrated like a wedge into the young Barents Sea Platform.

The events that took place in the Baltic Shield frame could not but have had an active influence on its internal physical state. As a result, in the eastern part of the shield, an almost orthogonal fault system formed, with northwestern and northeastern branches up to a meridional direction (Fig. 4). The nature of these deformations predetermined the emergence of another fault system, which formed as a result of the decomposition of forces. The formation of the submeridional-sublatitudinal orthogonal system in the described time period had a secondary nature and occurred without any significant displacements along the faults. The inevitable occurrence of tensile stresses in the eastern part of the Baltic Shield formed a number of rift structures. Within the limits of the Kola Peninsula and its frame, the White Sea (Kandalaksha-Dvina) and Norway-Mezen rift systems are distinguished, enveloping it from the north and south and marking NW-trending faults. As a result of closing of the Paleoural Ocean and formation of a regular fault system in EEP lithosphere, a system of SW-trending rifts formed somewhat later, marked by the water area of the White Sea Strait, extending to Lake Ladoga and farther to the Baltic Sea. Due to this, to the east of the White Sea, the two NW-trending rift systems were joined and the structural-material ensemble of the Mezen syneclise was transformed.

The of the Kandalaksha-Dvina (White Sea) rift system extends from the Kola Peninsula to Timan, with a length of $\sim 900 \mathrm{~km}$ and a width of $50-270 \mathrm{~km}$ [6]. In the northwestern part, the Kandalaksha rift gradually wedges out, while near the Tersky coast, the Ermakov graben branches off NNW [3]. The Barents Sea rift system can be traced from Laksefjord and Tanafjord on the north coast of Norway, along the Murmansk coast of the Kola Peninsula and farther southeast. Its total length is about $1500 \mathrm{~km}$, with a width of up to $200 \mathrm{~km}$. In the region of the north coast of Norway, this rift system pinches out and looks like a right lateral strike-slip fault.

The Mezen syneclise, within which the Arkhangelsk diamondiferous province developed, formed as a result the Baikalian, then Caledonian-Hercynian stages of geodynamic activity. It first occurred on the margin of the Russian Plate as a result of its junction with the Barents Sea-Pechora Plate in the Riphean and represented a typical foredeep on the Archean basement. Somewhat later, the formation of the Kandalaksha-Dvina (White Sea) Riphean aulacogen took place, as a reflection of the Dalslandic folding phase in the west of the Baltic Shield. Still later, the processes of the Caledonian and Hercynian tectonogenic phases were overprinted on structures of the Mezen syneclise, which undoubtedly complicated the internal structure of the region (Fig. 5).

The basement of the Mezen syneclise is of Archean or Early Proterozoic age. It is represented by intensely dislocated and, to varying degrees, metamorphosed (ultrametamorphosed) volcano-sedimentary volcanic complexes, as well as mafic and felsic intrusions, which are combined into tectonic complexes of different ages.

The lower part of the platform cover is represented mainly by the Upper Proterozoic terrigenous complex, which combines marine, coastal, and continental rocks and is subdivided into two structural stages: the lower (Middle Riphean) and upper (Upper Riphean). This is overlain by the Upper Proterozoic-Phanerozoic complex, which is subdivided into two structural stages: lower (Upper Proterozoic) and upper (Phanerozoic). The lower structural level consists of Upper Vendian deposits and is distributed over the entire syneclise. The upper Phanerozoic structural stage is subdivided into three sub-stages: lower (Silurian-Devonian), middle (Carboniferous-Lower Permian), and upper (Upper Permian-Cenozoic) [12].

According to $[12,16]$, the lower part of the platform cover section formed synchronously with intense tectonic processes and formation of the NorwegianMezen system of Riphean aulacogens (Fig. 5).

Analysis of the distribution system of depressions, troughs, and uplifts within the Mezen syneclise shows that they are spatially located with surprising regularity. Thus, an extended series of depressions tending towards the Timan Ridge are apparently foredeep structures, while the rest are separated from them by a system of uplifts and reflect the wedging-out conditions of Phanerozoic rift systems (Fig. 5).

Explosion pipes of alkaline-ultramafic and kimberlite compositions, which penetrated the basement of the Mezen syneclise, became an integral part of a large igneous province (LIP) of this region.

The processes of Caledonian-Hercynian activation on the Baltic Shield led to emplacement of a number of igneous complexes, which formed on the shoulders of these structures, in rift development zones, as well as at the intersections of the largest lineaments (Fig. 6). Owing to this, a Paleozoic alkaline-ultramafic, melilitite, and kimberlite magmatic province formed within the Baltic Shield and north of the Russian Plate.

In particular, in the central Kola Peninsula, a complex of central-type nepheline syenites and alkaline ultramafic intrusions has developed (Fig. 1). There are two age intervals for this magmatism. Early intrusive bodies, explosion pipes, and dikes were emplaced 480-400 Ma ago and form a zone stretching northwest along the coast of Kandalaksha Bay and farther, which includes the Kovdor massif [3, 17]. Later episodes of magmatism have an age of 400-320 Ma and are con- 


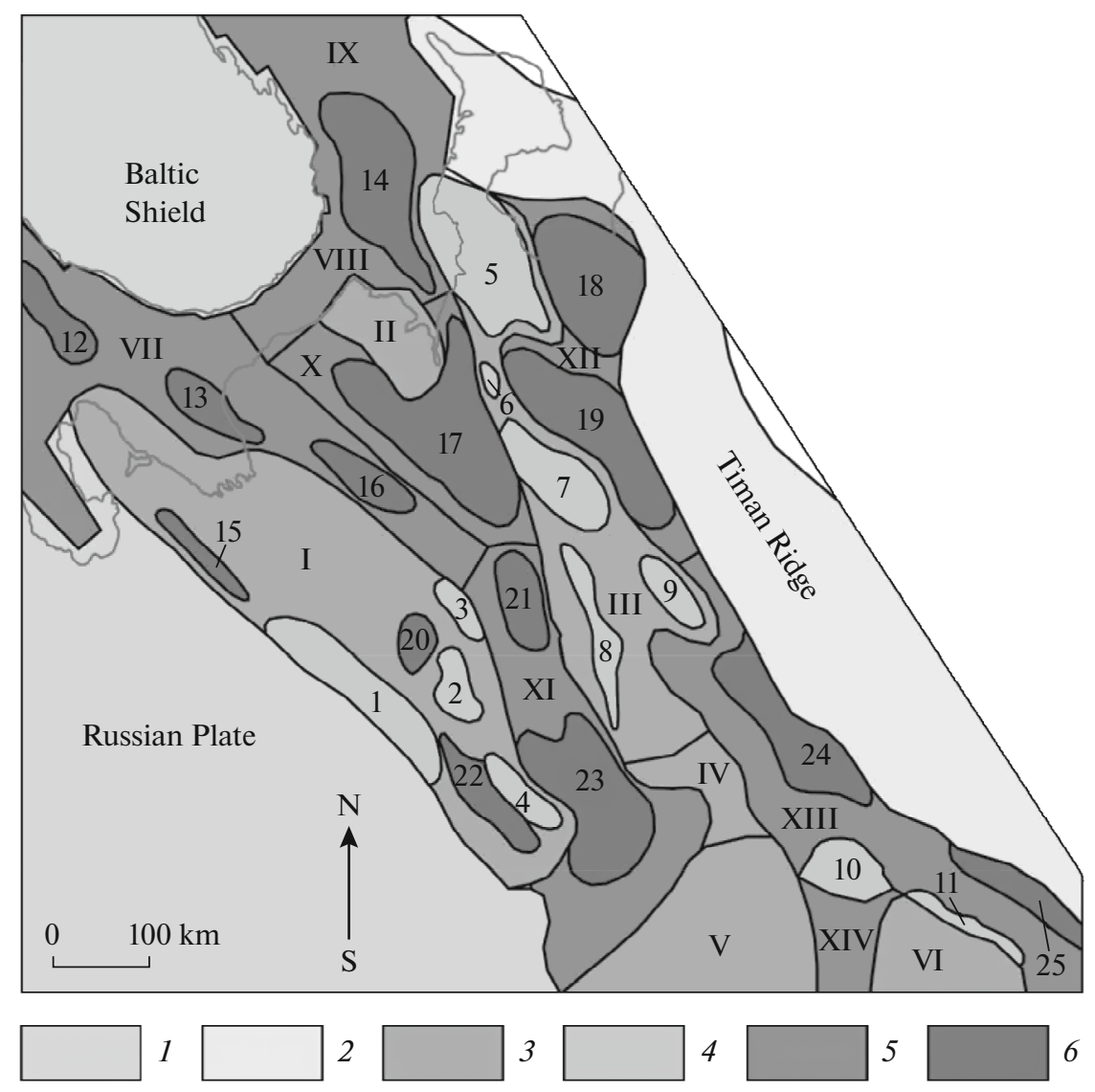

Fig. 5. Tectonic structure of Mezen syneclise basement (after [16] with changes and additions): (1-2) structures of frame of Mezen syneclise; (3-4) basement highs within syneclise: I-VI, first-order: I, North Dvina monocline and Arkhangelsk arch; II, Nessko-Tylugsky inlier; III, Mezen Megarise; IV, Ertym saddle; V, Sysolsky vault; VI, Komi-Permyay arch; (1-11) secondorder: (1) North Dvina Rise; (2) Yul'skoe uplift; (3) Karpogorsky Rise; (4) Uftyugskoe uplift; (5) Tylugskoe uplift; (6) Lower Peskoe uplift; (7) Tsenogorskoe uplift; (8) Vashkinsky Rise; (9) Koslansky Rise; (10) Storozhevskoe uplift; (11) Prubsky Rise; (5-6) deflections of basement within syneclise: VII-XIV, first-order: VII, Kandalaksha-Keretsky trough; VIII, White Sea Straight trough; IX, Voronka trough in White Sea; X, White Sea-Leshukonsky trough; XI, Pinega trough; XII, Peshsko-Safonovsky trough; XIII, Vychegodsky trough; XIV, Kirov-Kazhimsky trough; (12-25) second-order: (12) Kandalaksha basin; (13) West Keretsky basin; (14) Prikaninsky basin; (15) Onega basin; (16) Keretsky basin; (17) Leshukonsky basin; (18) Peshsky basin; (19) Safonovsky basin; (20) Poksheng basin; (21) Middle Pinega basin; (22) Toyma basin; (23) Upper Pinega basin; (24) Vishera basin; 25, North Keltmen basin.

fined to NE- and N-trending faults [3, 8]. The revealed regularity confirms our earlier conclusions about multistage structure-forming processes in the region and associated magmatism [11, 22].

On the north coast of Kandalaksha Bay in the White Sea, a dolerite dike complex with submeridional and northeastern striking has been noted, corresponding in composition to oceanic basalts. Northeaststriking lamprophyre dikes, picrite, melilitite, and kimberlite explosion pipes were also recorded there, on both coasts. In the area of Lake Onega, a field of diamondiferous kimberlite explosion pipes was revealed, and near Kostomuksha, lamproite diatremes (Fig. 6). In Arkhangelsk oblast, in the development zone of the Norway-Mezen rift system, the large Zimneberezhnoe melilitite and kimberlite field has been identified. On Franz Josef Land and Svalbard, a younger, Cenozoic magmatism is expressed by the development of a complex of subparallel NW-striking dikes and mafic blanket volcanics, as well as dolerite and dolerite-basalt sills, which intruded into Upper Triassic deposits and most likely marked processes of opening of the Arctic Ocean in the Eocene.

The eastern part of the White Sea basin, including the strait, coincides with a large node of the intersection of deep-seated faults, the kinematics of which have an extensional character of (Fig. 4). That is why intense magmatism is widespread in the adjacent areas, coupled with the age of their formation. The persistent isostatic uplift of the northeastern part of the Baltic Shield during the Paleozoic-Cenozoic and the uplift of deep crustal levels to the surface should have inevitably led to the formation of rich placers in the bottom sediments of the semienclosed White Sea basin [4]. 


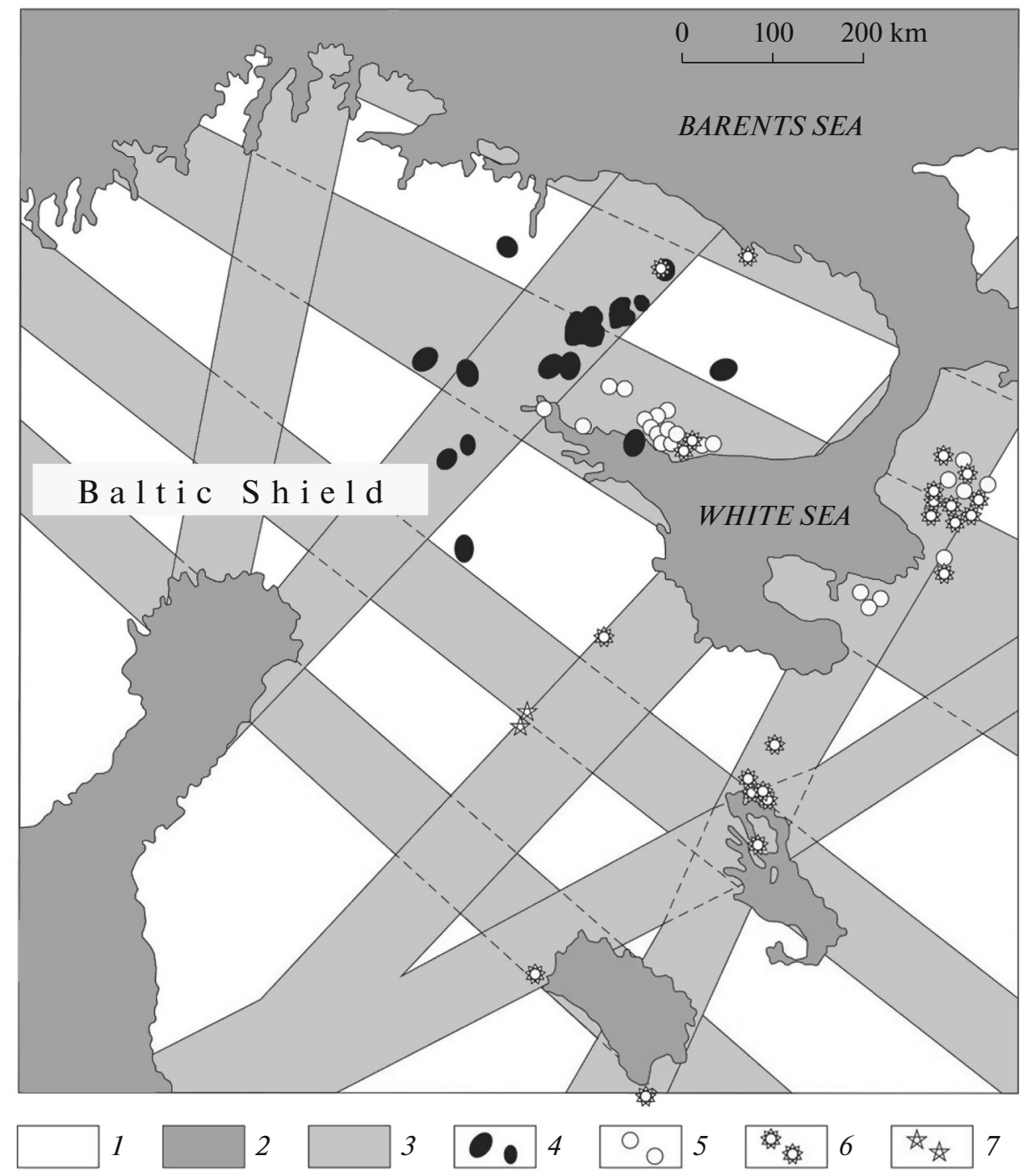

Fig. 6. Sketch map of tectonics and distribution of main intrusive massifs and explosion pipes of Paleozoic age in northeast part of Baltic Shield: (1) surface of Baltic Shield; (2) contour of sea and other water areas; (3) linear zones of concentration of Paleozoic deep-seated tectonic faults; (4) alkaline-ultramafic intrusion; (5) melilitite explosion pipes; (6) kimberlite explosion pipes; (7) lamproite explosion pipes.

\section{ZONING OF AREAS OF LOCALIZATION OF ALKALINE-ULTRAMAFIC AND KIMBERLITE MAGMATISM AND THE DIAMOND POTENTIAL OF THE EASTERN BALTIC SHIELD}

The spatial localization patterns of the described igneous complexes are characterized by the strict dependence of their location in the region. Intrusions of alkaline-ultramafic and carbonatite composition are located mainly in the central Kola Peninsula and North Karelia. They barely overlap with the zone of picrite and melilitite magmatism, tending spatially towards the Tersky coast of the Kola Peninsula (Fig. 1). To the east, in Arkhangelsk oblast, there is a zone of exclusively kimberlite magmatism, which also has strict spatial limitations (Fig. 5). The resulting depen- dence of the spatial distribution of magmatic complexes of different composition and pathway to the surface indicates a consistent change in the depth of magma formation, which increased along the Kandalaksha-Dvina rift systems from northwest to southeast. Most likely, the late rift system at an acute angle opened the magma chambers buried in the Proterozoic paleosubduction zone (Fig. 1).

Recall that, according to [7], the depth of origin of alkaline ultramafic magmas ranges from 80 to $100 \mathrm{~km}$, while kimberlite magmas form at depths from 150-180 to $200-220 \mathrm{~km}$. In this case, melilitite magmas occupy an intermediate value. This is why the mutual spatial coincidence of the zones of Early Proterozoic paleosubduction and Caledonian-Hercynian rift formations are of paramount importance for predicting the areas of localization of kimberlite magmatism. 


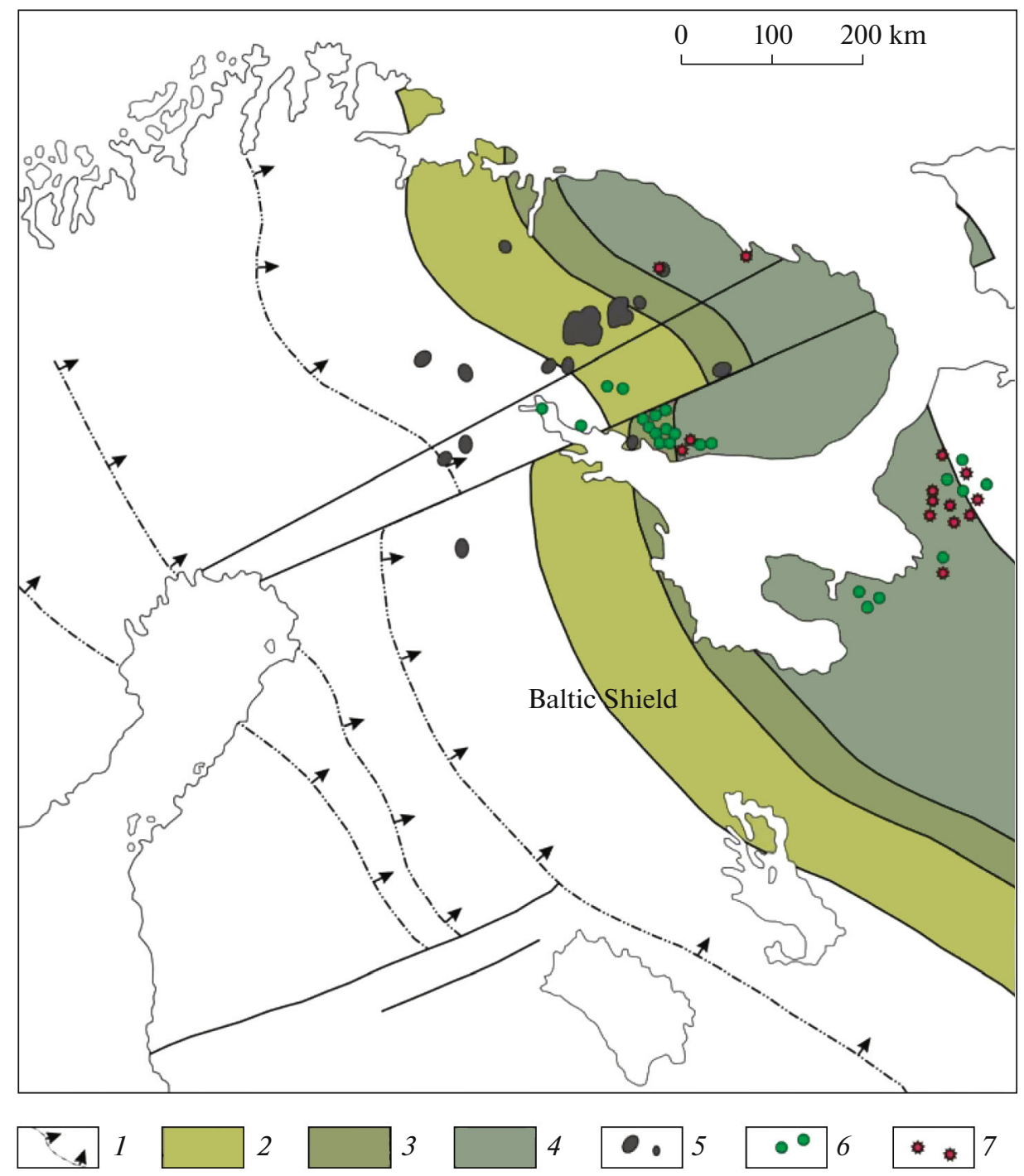

Fig. 7. Example of projection onto surface of zones of localization of buried melts relative to selected subduction zone: (1) Svecofennian paleosubduction zone (1.9-1.8 Ga ago), with respect to which projections were constructed; (2) area of equilibrial existence of buried alkaline-ultramafic magmas; (3) same for picrite,melilitite, and carbonatite diatremes; (4) same for kimberlite and lamproite explosion pipes; (5) intrusions of alkaline-ultramafic rocks and carbonatites; (6) picrite, melilitite, and carbonatite explosion pipes; (7) kimberlite and lamproite diatremes.

The movement of oceanic plates during closing of the Svecofennian Ocean occurred approximately in a northeastern direction under the Karelia-Kola Archean megablock. The imagined continuation of the planes of incidence of these zones makes it possible to estimate the depth of the surface of absorbed oceanic crust as a function of distance from the front of the former plate subduction zone. As an example, a paleosubduction zone was chosen that frames the Archean Karelia-Kola region from the west (Fig. 7). However, to calculate the penetration depths of crustal material in this zone, it is necessary to know the angle of subsidence of oceanic plates under continental plates in the Early Proterozoic. This problem is very difficult and in theory impossible to solve without ambiguity. As a first approximation, we can use a rule of thumb: the higher the rate of plate subduction, the flatter the subduction zone itself becomes. Thus, under the Mariana Island Arc, the Pacific Plate is moving at a rate of $\sim 4 \mathrm{~cm} /$ year, while the slope of the Wadati-Benioff zone reaches $\approx 70^{\circ}$ or more. Under the Kuril Arc, the subduction rate is $\approx 7-9 \mathrm{~cm} /$ year, at an angle of $\approx 45^{\circ}$. Under the Andes of South America, the Nazca plate is subducting at a rate of about $\approx 15 \mathrm{~cm} /$ year, and the angle of inclination of the slab is reduced to $30^{\circ}$.

In the Early Proterozoic, the average rate of lithospheric plate movement was approximately five to six times higher than the modern one, reaching 25$30 \mathrm{~cm} /$ year [24]. Therefore, it should be expected that 


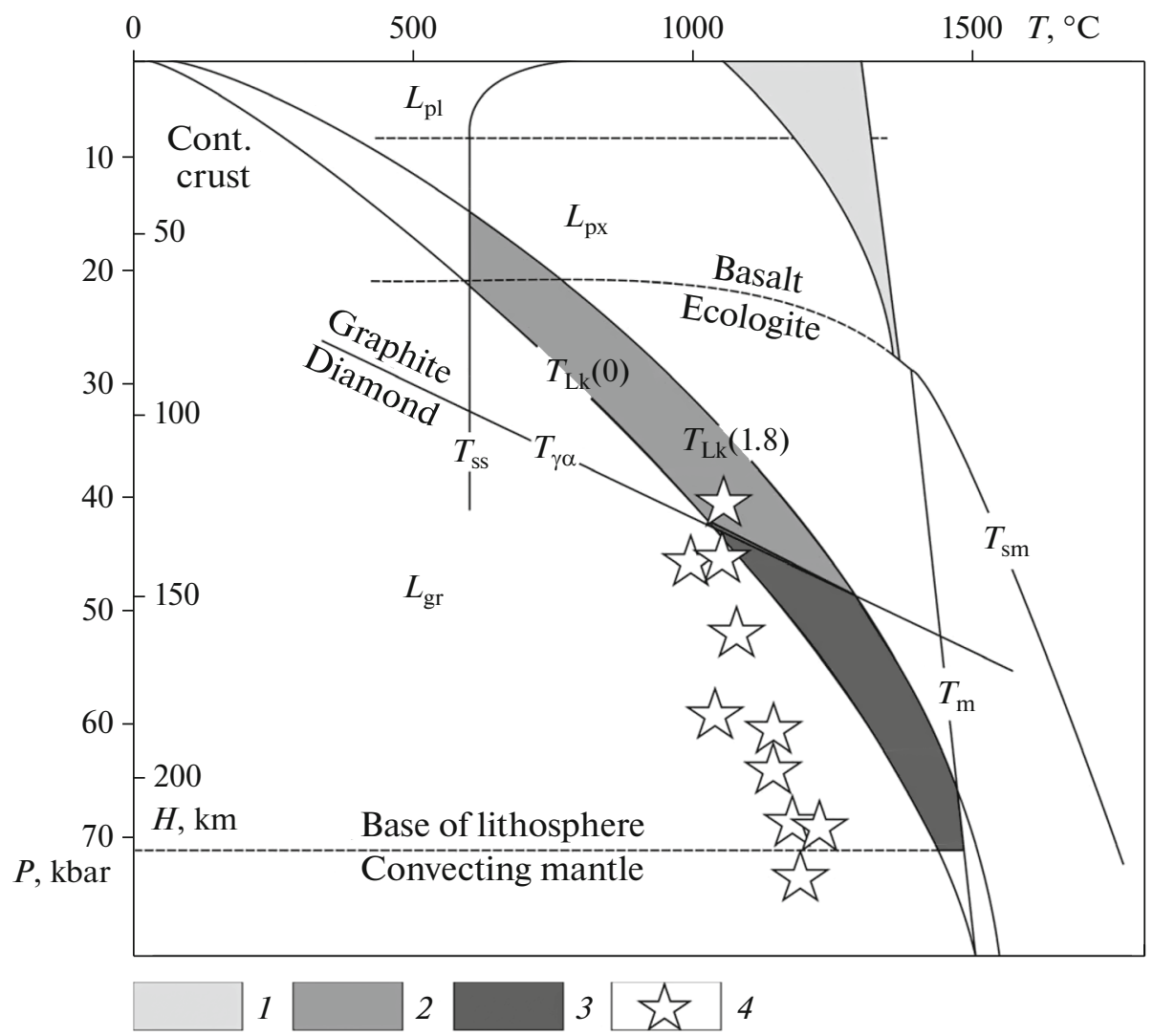

Fig. 8. Depth-temperature melting conditions of alkaline-ultramafic and kimberlite magmas [22]: $T_{\mathrm{m}}$, mantle temperature; $T_{\mathrm{sm}}$, solidus temperature of mantle material; $T_{\gamma \alpha}$, transition temperature of graphite, diamond; $T_{1 \mathrm{k}}(0)$, modern continental geotherm; $T_{\mathrm{lk}}(1.8)$, continental geotherm that existed $1.8 \mathrm{Ga}$ ago; $L_{\mathrm{pl}}, L_{\mathrm{px}}$ and $L_{\mathrm{gr}}$, areas of stable existence of plagioclase, pyroxene, and garnet lherzolites; $T_{\mathrm{ss}}$, melting point of water-saturated sediments. (1) Area of existence of basalt melts; (2) area of existence of alkaline-ultramafic, alkaline-carbonatite, and calcium-carbonatite melts; (3) area of existence of diamondiferous deep-seated kimberlite and lamproite melts; (4) area of formation of natural diamonds.

in that distant epoch, the minimum angles inclination of the plate subduction zones decreased to $20^{\circ}$, although these zones could also have been more steeply inclined. If the positions of the front of the subduction zone and outcrops of alkaline-ultramafic intrusions or kimberlite explosion pipes are known, then the angle of inclination of the plunging lithospheric plate at that time can be determined much more accurately.

It should be noted here that with an en echelon arrangement of Early Proterozoic plate subduction zones, as is observed to the west of the Karelia-Kola Craton, a spatial combination of complexes of alkaline-ultramafic, depthwise-transitional carbonatite, melilitite, and even kimberlite magmatism is possible. Thus, the horizontal zoning of the distribution of intrusions is complicated by overprinted magmatism at different depths. For example, melilitite explosion pipes that developed on the Tersky coast of Kandalaksha Bay are located together with poorly diamondiferous kimberlite explosion pipes. The same pattern is observed in Arkhangelsk oblast, where kimberlites of the Zolotitsky and Kepinsky fields are adjacent to olivine and olivine-phlogopite melilitites of the Verkho- tinsky and Izhmozersky fields. The empirical calculation showed that the dip angle of the Early Proterozoic subduction zone was almost $23^{\circ}$. This is in perfect agreement with current data on the angles of inclination of subduction zones.

If we now assume that the maximum thickness of the continental lithosphere at the formation time of deep-seated melts reached $250 \mathrm{~km}$, then the maximum distance from the ancient plate subduction zone at which these episodes of diamondiferous magmatism can still be expected will be $L_{\max } \approx 650-700 \mathrm{~km}$ (Fig. 8). The minimum depth of diamondiferous melt formation is controlled by the intersection of the modern continental geotherm $T_{l}$ with the temperature boundary of the graphite-diamond phase transition $T_{\gamma \alpha}$ (Fig. 8). In our case, the point $T_{1}=T_{\gamma \alpha}$ corresponds to a depth of $130 \mathrm{~km}$. Consequently, the minimum distance from the suture zone to the zone of possible manifestation of diamondiferous magmatism is approximately $400 \mathrm{~km}$.

The zone of explosive of melilitite and nondiamondiferous kimberlite magmatism should be closer to the paleosubduction zone. The maximum distances in 
this belt coincide with the inner boundary of the area of manifestation of diamondiferous magmatism. The inner boundary of the explosive magmatism belt is determined by the minimum depth of deep-seated melts capable of "breaking through" to the Earth's surface without crystallization of magmas at intermediate near-surface levels. Judging by the calculations in Fig. 8, this depth is approximately $115 \mathrm{~km}$. Hence, we find that the minimum distance from the considered suture zone to the belt of explosive (diatreme) magmatism is approximately $320 \mathrm{~km}$ (Fig. 7).

Even closer to the front of the former plate subduction zone, there is a belt of intrusive alkaline-ultramafic magmatism. Its minimum distance from the suture zone is determined by the minimum existence depth of melts in the continental lithosphere, i.e., depth where the geotherm $T_{1 \mathrm{k}}$ intersects the temperature curve of melting pelagic sediments $T_{1}=T_{\mathrm{ss}}$ (Fig. 8). This depth is approximately $70 \mathrm{~km}$, from which we find that the inner boundary of the belt of intrusive magmatism is $190 \mathrm{~km}$ from the front of the former plate subduction zone (Fig. 7).

If the paleosubduction zone chosen by us as an example were the only one, then theoretically there should be no manifestations of deep magmatism closer than this distance. However, they are still observed. There are three well-grounded explanations for this.

First, it is possible that the ascent of deep-seated magmas to the surface during stretching of the lithosphere occurs not only along vertical fissures, but also along the inclined surface of the plate subduction zone itself, especially since it is also a zone of weakness in the lithosphere. If this is indeed the case, then intrusions of alkaline ultramafic magmas could have penetrated the continental crust at any distance from the suture zone in a wide strip from 0 to $320 \mathrm{~km}$.

Second, such intrusions could have occurred due to penetration of deep-seated melts from the second and third plate subduction zones in the rear of the selected paleosubduction zone (Fig. 1). On the one hand, this explains the magmatism outside the modeled areas, and on the other hand, it explains the presence of formations of different depths at a close distance from each other. Indeed, during the formation of en echelon subduction zones, which often form when a series of island arcs join together, a vertical multitiered system of magmatic reservoirs of various composition occurs.

Third, it is possible that a paleosubduction zone exists, which we did not identify due to poor knowledge of the territory or because it is overlain by a thick sedimentary cover.

Studies in recent years at the northern tip of the Kola region have expanded the areas of possible occurrence of diamondiferous magmatism on the Baltic Shield and in its frame [9]. As a result of many years of prospecting in Riphean sedimentary sequences (Rybachy and Sredny peninsulas), the authors discov- ered placer diamonds and their accessory minerals, which made it possible to speak of possible significant expansion of the boundaries of the Arkhangelsk diamondiferous province [32].

\section{CONCLUSIONS}

The proposed zoning method for possible manifestation of deep-seated magmatism determines only the fundamental possibility of finding certain complexes of deep-seated rocks in the study area. However, their detection becomes possible only in cases when all the necessary above-mentioned factors are combined into a single system.

In conclusion, it desirable to make a very interesting, important, and well-substantiated forecast of the discovery of new, yet unknown manifestations of diamondiferous kimberlite magmatism in the described region.

The point is that the ore-controlling Paleozoic rift system was established at an earlier large aulacogen of the Riphean age, which has a similar strike and which developed in the White Sea and Mezen syneclise. In the northwest of this aulacogen, magmatism was absent, since there was no break in the continuity of the continental lithosphere of the Baltic Shield. However, the aulacogen has a clearly pronounced wedgeshaped structure, which leads to large-scale expansion at its southeastern terminus. This, in particular, is indicated by the small-block keyboard structure of the Mezen syneclise (Fig. 5). If the formation of the Riphean aulacogen in it reached the stage of complete breakup of the lithosphere, then one should expect there an extensive coeval manifestation of kimberlite magmatism.

Today, the Mezen syneclise is overlain by thick $(2.0-2.5 \mathrm{~km})$ Paleozoic-Cenozoic sediments. Consequently, if magmatism took place in the Riphean, then kimberlites penetrated into the coeval sedimentary cover and were then buried by subsequent layers of the cover. The Riphean magmatic pulse should have been more extensive and have contained a larger amount of diamond-rich kimberlite magma than the Paleozoic pulse. The fact is that, first of all, the hottest and, therefore, richest magmas erupted, while for the second impulse, only residual melts were sufficient. An example of this is the Premier Pipe in South Africa, the formation age of which is attributed to the Proterozoic. In this pipe, some of the largest diamonds in the world were found: Cullinan $(3106.75 \mathrm{ct})$ and De Beers $(428.5 \mathrm{ct})$. The later, Mesozoic magmatic pulse in this region caused the formation of explosion pipes with smaller diamonds, but of no lesser quality.

Thus, the present-day appearance of the Arkhangelsk diamondiferous province can be substantially supplemented by the distribution field of the morediamondiferous Riphean-age kimberlite pipes hidden $2-2.5 \mathrm{~km}$ beneath the Paleozoic sedimentary cover. 


\section{OPEN ACCESS}

This article is licensed under a Creative Commons Attribution 4.0 International License, which permits use, sharing, adaptation, distribution and reproduction in any medium or format, as long as you give appropriate credit to the original author(s) and the source, provide a link to the Creative Commons license, and indicate if changes were made. The images or other third party material in this article are included in the article's Creative Commons license, unless indicated otherwise in a credit line to the material. If material is not included in the article's Creative Commons license and your intended use is not permitted by statutory regulation or exceeds the permitted use, you will need to obtain permission directly from the copyright holder. To view a copy of this license, visit http://creativecommons.org/licenses/by/4.0/.

\section{REFERENCES}

1. T. B. Bayanova, Age of Main Geological Complexes of the Kola Region and Duration of Magmatism Processes (Nauka, Moscow, 2004) [in Russian].

2. B. Ya. Vasserman, "Exploration of hydrocarbon resources of the Timan-Pechora oil and gas province at the beginning of the 21st century," Geol. Nefti Gaza, No. 2, 10-16 (2001).

3. V. R. Vetrin and M. M. Kalinkin, Reconstruction of Internal Crust Processes and Crust-Mantle Magmatism and Metasomatism According to Analysis of Deep Inclusions (Karelian Scientific Center, Russian Academy of Sciences, Apatity, 1992) [in Russian].

4. B. V. Gavrilenko, F. P. Mitrofanov, D. R. Zozulya, et al., "Prospective scattered diamond content in the Kola region," Vestn. Murmansk. Gos. Tekh. Univ. 3 (2), 235-244 (2000).

5. E. M. Galimov, "Geochemistry of carbon," Geokhimiya, No.2, 258-278 (1988).

6. M. I. Dobrynina, "Rifting in the geological history of the Precambrian of the northern part of the Russian plate," in Deep Structure and Geodynamics of Crystalline Sheds of the European Part of the USSR (Karelian Scientific Center, Russian Academy of Sciences, Apatity, 1992), pp. 71-78.

7. J. B. Dawson, Kimberlites and Their Xenoliths (Springer-Verlag, New York, 1980; Mir, Moscow, 1983).

8. O. B. Dudkin, F. M. Minakov, et al., Carbonatites of Khibiny (Kola Branch, Academy of Sciences of USSR, Apatity, 1984) [in Russian].

9. N. G. Zamozhnyaya, et al., Regional-Zonal Seismic Survey MOV-CDP on the Rybachy Peninsula Combined with High-Precision Gravimetry to Study the Geological Structure and Oil and Gas Potential of Riphean Sediments (Murmangeolkom Funds, Apatity, 2001) [in Russian].

10. Precambrian Isotope Geochronology (Nauka, Leningrad, 1989) [in Russian].

11. N. E. Kozlov, N. O. Sorokhtin, V. N. Glaznev, et al., Geology of Archaea of the Baltic Shield (Nauka, St. Petersburg, 2006) [in Russian].
12. D. A. Kuz'min, Candidate's Dissertation in GeologyMineralogy (Moscow, 2006).

13. V. N. Kuleshov, Isotopic Composition and Origin of Deep Carbonatites (Nauka, Moscow, 1986) [in Russian].

14. E. E. Milanovskii, Geology of Russia and Close Foreign Countries (Northern Eurasia) (Moscow State Univ., Moscow, 1996) [in Russian].

15. Explanatory Note to the Tectonic Map of the Barents Sea and Northern Part of European Russia, Scale 1: 2500000 (Institute of Lithosphere, Russian Academy of Sciences, Moscow, 1996) [in Russian].

16. B. A. Pimenov and N. A. Malyshev, "Assessment of resources and directions of geological exploration for oil and gas in the Mezen sedimentary basin," in Geology of combustible Fossils of the European North of Russia, Tr. Inst. Geol., Komi Nauchn. Tsentra, Ross. Akad. Nauk, no. 85 (Syktyvkar, 1995), pp. 26-40.

17. I. V. Polyakov and M. M. Kalininkin, "Diamonds and minerals are satellites in kimberlites and loose sediments of the Tersk coast of the Kola Peninsula," Zap. Vses. Miner. O-va, No. 1, 96-101 (1993).

18. Seismological Model of Lithosphere of the Northern Europe: Lapland-Pechenga Region, Ed. by N. V. Sharov (Karelian Scientific Center, Russian Academy of Sciences, Apatity, 1997) [in Russian].

19. A. P. Simonov, D. M. Guberman, Yu. N. Yakovlev, et al., "Riphean oil of the Rybachii Peninsula: a myth or a key to a fundamentally new trend in oil and gas exploration on the shelf of the Barents Sea?" Vestn. Murmansk. Gos. Tekh. Univ. 1 (2), 121-140 (1998).

20. O. G. Sorokhtin, Doctoral Dissertation in GeologyMineralogy (Moscow State Univ., Moscow, 2001).

21. I. O. Sorokhtin, N. E. Kozlov, V. N. Glaznev, and I. V. Chikirev, "Geology and potential oil-gas capacity of the Rybachiy Peninsula (Kola Peninsula)," Geol., Geofiz. Razrab. Neft. Mestorozhd., No. 5, 14-19 (2011).

22. O. G. Sorokhtin, F. P. Mitrofanov, and N. O. Sorokhtin, Global Earth's Evolution and Origin of Diamonds (Nauka, Moscow, 2004) [in Russian].

23. O. G. Sorokhtin, F. P. Mitrofanov, and N. O. Sorokhtin, Origin of Diamonds and Their Resources in the Eastern Part of Baltic Shied (Karelian Scientific Center, Russian Academy of Sciences, Apatity, 1996) [in Russian].

24. O. G. Sorokhtin and S. A. Ushakov, Evolution of the Earth (Moscow State Univ., Moscow, 2002) [in Russian].

25. V. E. Khain, Tectonics of the Continents and Oceans in 2000 (Nauchnyi Mir, Moscow, 2001) [in Russian].

26. Babel Working Group, "Integrated seismic studies of the Baltic Shield using data in the Gulf of Bothnia region,” Geophys. J. Int. 112 (3), 305-343 (1993).

27. C. S. Eldrdge, W. Compston, I. S. Williams, et al., "Isotope evidence for the involvement of recycled sediments in diamond formation," Nature 353, 649-653 (1991). 
28. T. C. Pharaon and J. A. Pearce, "Geochemical evidence for the geotectonic setting of Early Proterozoic metavolcanic sequences in Lapland," Precambrian Res. 25, 283-308 (1984).

29. M. E. Raaben, V. V. Lubtsov, and A. A. Predovsky, "Correlation of stromatolitic formations of northern Norway (Finnmark) and northwestern Russia (Kildin Island and Kanin Peninsula)," in Geology of the Eastern Finnmark: Western Kola Peninsula Region (Geological Survey of Norway, Trondheim, 1995), pp. 233-246.

30. N. O. Sorokhtin, G. V. Chilingar, N. E. Kozlov, and S. Shin, "Geodynamic evolution of oil and gas basins in the European part of the Eurasian Arctic shelf," Energy Sources, Part A 34 (22), 2092-2103 (2012).

31. N. O. Sorokhtin, The Origins of Natural Diamonds (Wiley, Chichester, 2019).
32. N. O. Sorokhtin, N. E. Kozlov, and V. Yu. Kalatchev, "The first find of diamond on the Sredny and Rybachy Peninsulas in the north-eastern Baltic Shield," Vestn. Murmansk. Gos. Tekh. Univ. 22 (1), 36-47 (2019).

33. O. G. Sorokhtin, G. V. Chilingarian, and N. O. Sorokhtin, "Evolution of Earth and its climate," in Developments in Earth and Environmental Sciences (Elsevier, Amsterdam, 2011), Vol. 10.

34. V. A. Vernikovsky, D. V. Metelkin, A. E. Vernikovskaya, et al., "Early stages of evolution of the arctic margins (Neoproterozoic-Paleozoic) and plate reconstructions," in Proceedings of the International Conference on Arctic Margins VI "Origins of Northeastern Russia: Paleomagnetism, Geology, and Tectonics (ICAM-VI), " Abstracts of Papers (Fairbanks, 2011). 